\title{
Description of an ancient social bee trapped in amber using Diagnostic Radioentomology
}

Mark K. Greco ${ }^{1,2^{*}}$, Patricia M. Welz ${ }^{4}$, Mark Siegrist ${ }^{5}$, Stephen J. Ferguson ${ }^{4}$, Peter Gallmann ${ }^{3}$, David W. Roubik ${ }^{6}$, Michael S. Engel ${ }^{7,8}$

1. INVERT Group, Department of Electrical and Electronic Engineering University of Bath BA2 7AY UK

2. Departement für Klinische Veterinärmedizin, Vetsuisse-Fakultät, Universität Bern, CH-3001 Bern, Switzerland

3. Swiss Bee Research Institute, Agroscope Liebefeld-Posieux Research Station (ALP), CH-3033 Bern, Switzerland

4. Institute for Surgical Technology and Biomechanics, University of Bern, CH-3014 Bern, Switzerland

5. Department of Clinical Research, University of Bern, Bone Biology Group, CH-3010 Bern, Switzerland

6. Smithsonian Tropical Research Institute, Balboa, Ancón, Republic of Panamá

7. Division of Entomology (Paleoentomology), Natural History Museum, and Department of Ecology \& Evolutionary Biology, 1501 Crestline Drive - Suite 140, University of Kansas, Lawrence, Kansas 66049-2811, United States

8. Division of Invertebrate Zoology (Entomology), American Museum of Natural History, Central Park West at $79^{\text {th }}$ Street, New York, New York 10024-5192, United States

*Author for correspondence:

E-mail: M.K.Greco@bath.ac.uk, phone: +44 - (0)1225 383317, fax: +44 - (0)1225 383310 


\begin{abstract}
The application of non-invasive imaging technologies using X-radiation (diagnostic radioentomology, 'DR') is demonstrated for the study of amber-entombed social bees. Here we examine the external and internal morphology of an Early Miocene (Burdigalian) stingless bee (Apinae: Meliponini) from the Dominican Republic using non-destructive, X-ray microtomography analysis. The study permits the accurate reconstruction of features otherwise obscured or impossible to visualize without destroying the sample, and allows diagnosis of the specimen as a new species, Proplebeia adbita Greco and Engel.
\end{abstract}

Keywords Proplebeia, stingless bee, diagnostic radioentomology, Miocene, Burdigalian, MicroCT, amber

Short Title New Tertiary social bee species described using DR 


\section{Introduction}

Bees are a diverse lineage and many are important pollinators, familiar to the entomologist and layman alike. They range from mostly solitary species, to semi-social, to those living in eusocial colonies (Michener, 1974, 2007). The monophyly and higher classification of bees have been well established, and the relatively stable relationships among these broader groups are being refined continually through the application of morphological and molecular techniques. Current evidence supports the conclusion that bees evolved from among the apoid wasps at least 125 million years ago (Engel, 1996, 2000, 2001a, 2004, 2011; Ohl and Engel, 2007; Michener, 2007) and most classifications place them as the clade Anthophila, likely sister to the family Crabronidae (Ohl and Bleidorn, 2006; Engel, 2011). All extant species, apart from the necrophagous hypogea group of Trigona (Roubik, 1982; Camargo and Roubik, 1991; Noll et al., 1996; Noll, 1997; Mateus and Noll, 2004; Camargo, 2008) and the tiny species of the genus Lisotrigona (Bänziger et al., 2009; Bänziger and Bänziger, 2010), feed their immatures a mixture of pollen and nectar (Roubik 1989; Michener, 2007; Engel, 2011). Pollen and/or floral oil collection and transport by adults were made possible by a suite of behavioural and morphological adaptations, novelties that contributed to the rapid diversification of the angiosperms in the Cretaceous (Thorp, 1979; Soltis et al., 2003; Grimaldi and Engel, 2005).

The bees have several characteristic morphological attributes such as branched or plumose body setae and broadened metabasitarsi (Michener, 2007; Engel, 2011). The highly eusocial stingless bees comprise the tribe Meliponini among the corbiculate Apinae (e.g., Engel, 2001b, 2005; Cardinal and Packer, 2007; Michener, 2007). In addition to extensive morphological and molecular data (e.g., Cardinal and Packer, 2007; Kawakita et al., 2008), the monophyly of corbiculate apines has been supported by studies investigating their internal anatomy. For example, Serrão (2001) noted that the proventricular morphology of Euglossini and Bombini consists of long columnar plates, plates with triangular apices in Apini, while the Meliponini have slender and elongate plates. Accordingly, the proventriculus can be used as an important diagnostic structure for bee taxonomy (Greco et al., 2008), among a suite of other internal anatomical features (Engel, 2011). The examination of such characters often requires considerable manipulation, dissection, sectioning, or even complete destruction of the specimen. Thus, the practical application of such data is at times hampered by the methods employed.

Traditionally, the morphological classification of bees has been conducted with the aid of dissecting microscopes which use light. The technique is understandably limited when used for amber inclusions (e.g., Wille and 
Chandler, 1964; Michener, 1982; Engel, 1995, 1996, 1997; Rozen, 1996; Camargo et al., 2000; Oliveira, 2002; Hinojosa-Díaz and Engel, 2008) particularly with specimens preserved in opaque pieces (Lak et al., 2008, 2009). Schlüter and Stürmer (1982) attempted to address methods of examining insect inclusions in opaque amber pieces as well as supplement traditional light microscopic study of even clear specimens. Those researchers and Gerling and Hermann (1978), Gerling et al. (1981), and Velthuis and Gerling (1983) produced traditional x-ray radiographs which provided the first, albeit limited, steps toward enhanced visualisation of cryptic bee behaviour and fossil material. More recently, detailed information for the study of bees has been obtained with the use of scanning electron (SEM) (e.g., Serrão, 2001, 2005) and transmission electron microscopy (TEM) (e.g., Araujo et al., 2005). While SEM and TEM studies currently provide the highest level of detail, sample preparations are laborious and are often invasive to outright destructive (e.g., Serrão, 2001). SEM and TEM can be used for the investigation of amber inclusions (e.g., Grimaldi et al., 1994; Engel, 2001a); however, these methods are generally not suitable because they require destruction of the material.

X-ray computerised tomography (CT) has been adopted previously to visualise macroscopic characteristics of insects and their behaviour (Tollner, 1991; Fuchs et al., 2004; Greco et al., 2005, 2006, 2009; Perna et al., 2008). Conventional microfocus and synchrotron based MicroCT is now emerging as a new method for the noninvasive imaging of insects at the microscopic level (e.g., Hörnschemeyer et al., 2002; Johnson et al., 2004, Wirkner et al., 2004; Tafforeau et al., 2006; Betz et al 2007; Greco et al., 2008; Heethoff et al., 2009). The basic principles of conventional microfocus source MicroCT are similar to those used in medical CT scanners; however, it is now possible to achieve spatial resolutions down to a few micrometers (Bettuzzi et al., 2004; Feeney et al., 2006). Diagnostic Radioentomology (DR) is the collective term used for the non-invasive study of insects using X-radiation (radiographs, MacroCT, and MicroCT). In this paper we describe the internal and external morphology of an ancient social bee trapped in amber using non-invasive and non-destructive DR techniques.

\section{Materials and Methods}

\section{Sample and sample preparation}

The sample selected for this study was collected from the La Bucara mine in the Dominican Republic (19 $34^{\prime} \mathrm{N}$, $\left.70^{\circ} 40^{\prime} \mathrm{W}\right)$. The amber is a polished, semi-clear, brown piece with many inclusions including a stingless bee at the thickest end (Fig. 1). The posterior of the bee's metasoma is at the extreme periphery of the piece's thick end 
and the apices of both forewings have broken away from the sample over time. Age estimates of Dominican amber vary considerably in the literature (e.g., Lambert et al., 1985; Grimaldi, 1995; Iturralde-Vinent and MacPhee, 1996). Nonetheless, most data indicate that the age of most Dominican amber, including the material in this study, is 16-19 Ma (Grimaldi, 1995; Camargo et al., 2000; Grimaldi and Engel, 2005). The sample had been polished prior to this study and thus required no extra preparation.

\section{Light microscopy}

For light microscopy, the bee was viewed using a Leica MZ12 stereomicroscope, Leica Microsystems GmbH Ernst-Leitz-Strasse 17-37 35578 Wetzlar. The Leica MZ12 has distortion-free 10x eyepieces with a resolution of 375 line-pairs/mm. Ideally, because of the thickness of the amber, air bubble inclusions and fractures present in the sample, it would have been better to cut the piece prior to light microscopy examination, however the sample was intentionally preserved to enable visualisation of the other biological inclusions using DR in future studies.

\section{DR-MicroCT}

\section{Scanning Phase}

MicroCT scans were performed using three systems: a commercial benchtop system, a custom design scanner and the facility for MicroCT available at the SYRMEP beamline of the Elettra light source in Trieste (Italy). The first scans were performed at the Department of Clinical Research, University of Bern, using a MicroCT 40 system (by Scanco Medical AG, Brüttisellen, Switzerland). Prior to scanning, the sample was placed in a 20.5mm cylindrical sample holder between the X-ray source and the CCD detector (Fig. 2). This sample positioning procedure for the scanning phase of a DR examination is the same for desktop and Beamline scanning.

The following Scanco scanning parameters were used:

- Tube operating conditions: HV peak was set at $45 \mathrm{kV}$ and current was $177 \mu \mathrm{A}$

- High Resolution mode (1000 Projections $/ 180^{\circ}$ )

- Image Matrix of 2048 x 2048 pixels

- $\quad$ Isotropic Voxel size $10 \square \mathrm{m}$

- Integration time $3 \mathrm{~s}$

- $\quad$ total number of 610 slices 
- $\quad$ measurement time $10.5 \mathrm{~h}$

Scans were converted to axial orientation with the Scanco software and 998 bitmap images (16 bit grey scale) were stored for $2 \mathrm{D}$ viewing and $3 \mathrm{D}$ rendering as a $983 \mathrm{Mb}$ dataset.

The other scans were performed at Elettra, the third generation synchrotron light source in Trieste (Italy) using two facilities for MicroCT: a conventional benchtop system (TOMOLAB) based on a micro-focus generator and the MicroCT system available at the SYRMEP beamline (Abrami et al., 2005).

The Elettra facilities are complementary in their use. While the beamline setup advantages include characteristics such as high spatial coherence, X-ray monochromaticity and parallel beam geometry, it is limited in the energy range as well as in the vertical beam dimension. TOMOLAB's advantages are its polychromatic spectrum peaked at high X-ray energies, and high magnification due to the cone beam geometry which are suited for studying larger samples and/or samples with higher absorption.

TOMOLAB scans were performed using the following scanning parameters:

- $\quad$ Tube operating conditions: HV peak was set at $40 \mathrm{kV}$ and current was $200 \square \mathrm{A}$

- $\quad$ Source-to-sample distance: $12 \mathrm{~cm}$

- Source-to-detector distance: $36 \mathrm{~cm}$

- $\quad$ Isotropic Voxel size: $8 \square \mathrm{m}$

- $\quad$ Exposure time: $2.7 \mathrm{~s}$

- $\quad$ Number of projections: 2400 over $360^{\circ}$

- Measurement time: $1: 48 \mathrm{~h}$

SYRMEP Beamline scans were performed using the following scanning parameters:

- X-ray energy: $15 \mathrm{keV}$

- Sample to detector distance: $20 \mathrm{~cm}$

- $\quad$ Number of projection (over $180^{\circ}$ ): 1800

- $\quad$ Isotropic Voxel size: $9 \square \mathrm{m}$

- $\quad$ Exposure time: $0.9 \mathrm{~s}$

- $\quad$ Measurement time 1:48 h

The height of the beam was about $4 \mathrm{~mm}$ and because the sample thickness was approximately $7 \mathrm{~mm}$ two scans were needed to cover the entire sample.

The above methods for the scanning phase of DR are usually performed by staff at the MicroCT facilities. Entomologists who would prefer to perform the scans can be trained just as one is trained for use of SEM or TEM equipment. 


\section{Image processing}

Using multi-planar reformatting (MPR) algorithms, the 2D bitmaps were reformatted into a 3D model. The 3D reconstruction and analyses of the 2D bitmaps were performed as in Greco et al. (2005). The sample was further manipulated by adjusting window levels (WL) and window widths (WW) to enhance visualisation of the morphological structures. Greatest visual enhancement was achieved at WL 110 and WW 35. The narrow WW reflected the closeness of the amber density to that of the bee's cuticle. For greater flexibility in software usage, the commercial VGSTUDIO MAX 2.0 voxel data analysis and visualization software (Volume Graphics GmbH, Wieblinger Weg 92a, 69123 Heidelberg, Germany) was used while at the scanner workstations and BeeView 3D rendering software (DISECT Systems Ltd., Suffolk, UK) was used remotely on an office PC and laptop computer. The sample was viewed from many angles along randomly selected axes. Sections of the model were also removed along cutting planes which were positioned by using the computer mouse. The cutting planes acted like a virtual scalpel enabling visualisation of the bee's internal morphology without damaging the amber or its inclusions. Image magnification was performed when greater detail was required. Phylogenetic characteristics and morphological measurements were assessed with BeeView volume algorithms and on-screen linear callipers.

\section{Results}

\section{Light microscopy}

The colour of the bee was brown to dark brown; however, it is possible that the bee was black when alive and that the cuticular melanin was altered over time. Indeed, many amber inclusions may appear cleared as a result of diagenesis, which somewhat lightens the cuticle. Moreover, teneral adult stingless bees are often lighter in colouration and so the more brownish colour of the specimen cannot be considered diagnostic. Gross external morphological features of the bee, such as the flagellomeres, coxae, trochanters, and tibiae, were visible to about the level of the mesothorax. The air bubbles, fractures and general thickness of the amber piece prevented adequate visualisation of the more posterior morphology, including a lack of detail for the wings. Increasing light intensity created image degradation due to light diffracting from cracks, air bubbles, and generalised opacity of the amber. Decreasing light intensity made it difficult to optically visualise the bee's morphological features (Fig. 3). 


\section{DR-MicroCT}

Although the resolution of MicroCT is not as fine as SEM or TEM, and colour could not be discerned as with light microscopy, the images presented here demonstrate that DR was useful for viewing and assessing the external and internal morphology of amber inclusions accurately and for non-invasively identifying diagnostic morphological features (see also Pohl et al., 2010). DR is particularly useful for studying inclusions in opaque amber (Lak et al., 2008, 2009).

Gross external morphological features of the bee, such as the flagellomeres, the articulations of the coxae, trochanters, tibiae, and tarsi, including the corbiculae of the metatibiae and the broadened metabasitarsi, were well visualised in the 3D reconstructions (Fig. 4). In addition, gross internal structures, such as the brain (including details of its anatomical regions), direct and indirect flight muscles, and a loaded rectum were accurately represented (Fig. 5). Considering the specimen's age (16-19 Ma), the brain of this bee was particularly well preserved. The optic and antennal lobes were well reconstructed along with the dense central body and the protocerebral lobes (Fig 6). The retinal zone was also well preserved. Adhesion of the retinal zone to the proximal surface of the compound eyes and the corresponding region on the distal surface of the medullae was evidenced by a thin, dense film of tissue (Fig. 6).

\section{Taxonomy}

A brief diagnosis is provided for the new species recognized during this work. The species matches the generic diagnosis of Proplebeia as it is understood based on the revision of Camargo et al. (2000), an extinct genus of the stingless bee lineage which itself most likely has West Gondwanan origins (Michener 2007; Rasmussen and Cameron 2010). Morphological terminology follows that of Camargo et al. (2000), Engel (2001a), and Michener (2007), while the format for the diagnosis generally follows those features highlighted by Camargo et al. (2000) across species of Proplebeia. The species generally matches the description of the worker for $P$. dominicana (Wille and Chandler) provided by Camargo et al. (2000) except in those features discussed. Although characters of the vestigial sting apparatus are of some use in meliponine systematics (e.g., Michener, 1990), these sclerites could not be imaged relative to the surrounding amorphous and likely dessicated metasomal tissues. 
Proplebeia abdita Greco and Engel, new species

Diagnosis: The worker of the new species can be distinguished from those of other species of Proplebeia by the tridentate mandible (Fig. 7), with a slight emargination separating the three denticles (bidentate in all other Proplebeia), the presence of only 5-6 spinelike setae comprising the rastellum (7-9 in all other Proplebeia), and the relatively straight inner compound eye margins (slightly concave in other Proplebeia). Among the species of the genus, $P$. abdita is most similar to $P$. dominicana but, in addition to the aforementioned attributes, can be separated by second flagellomere slightly longer than the third (slightly shorter in $P$. dominicana) and the larger body size (ca. $3.8 \mathrm{~mm}$ in $P$. abdita, ca. $3.0 \mathrm{~mm}$ in $P$. dominicana). In the larger size, the new species more closely approximates $P$. vetusta $(3.8-4.4 \mathrm{~mm}$; forewing $2.88-3.16 \mathrm{~mm})$, but again the above attributes can separate the two species. In addition, $P$. abdita lacks the long, straight setae of the metasomal sterna that are present in P. tantilla. Moroever, P. tantilla is a considerably smaller species, the smallest for the genus (ca. $2.1 \mathrm{~mm}$ in length; forewing length $1.96 \mathrm{~mm}$ ).

Metrics: $\quad$ Total body length $3.79 \mathrm{~mm}$; forewing length $2.75 \mathrm{~mm}$, width $1.22 \mathrm{~mm}$; head width $1.36 \mathrm{~mm}$, length $1.25 \mathrm{~mm}$; compound eye width $0.33 \mathrm{~mm}$, length $0.81 \mathrm{~mm}$; metasoma width $1.03 \mathrm{~mm}$.

Holotype: $\quad$ Female (worker); Early Miocene (Burdigalian), Dominican amber; deposited in the Graptolites \& Fossil Arthropods collection of the Natural History Museum, London (accession number: NHM II 3044).

Etymology: The specific epithet is the Latin term abditum, meaning "concealed" or "hidden".

\section{Discussion}

DR permitted the comprehensive examination of this ancient specimen, where other methods were (in the case of light microscopy) and would be (in the case of SEM or TEM) found to be less reliable or unsuitable because of their destructive nature. We were able to accurately assess the bee's anatomical characteristics with BeeView volume visualisation algorithms and perform precise morphometric measurements with the program's on-screen linear calipers. As a result, we were able to produce details of a previously undescribed species, $P$. abdita Greco and Engel. This study demonstrated that all three methods were appropriate for visualising the specimen. Thus entomologists can consider which facility would provide the best option for them. In addition to the application of DR to this particular bee, its more extensive use on historical type material (e.g., the holotype of $P$. dominicana, other amber-preserved bees, or even unique specimens of rare modern species) will permit a more 
complete characterization of these taxa and comprehensive comparisons between them and their modern counterparts. Improved anatomical understanding of these taxa will greatly enhance phylogenetic reconstructions utilizing paleontological data and potentially revise our paleoecological perspectives of early pollinators. It is hoped that by highlighting the utility of DR for characterizing an ancient social bee, that these techniques might be more broadly applied to social bee biology and anatomy much in the tradition of Gerling et al.'s (1981) earlier applications of novel imaging methods, much in the way it has been applied to the study of termites and living stingless bees (e.g., Fuchs et al., 2004; Greco et al., 2005) as well as solitary bee species (e.g., Greco et al., 2006, 2008).

\section{Acknowledgements}

This work is dedicated to the memory of Prof. J.M.F. Camargo, leading authority on the systematics of stingless bees and who had initially participated in this work, suggesting that the specimen belonged to a new species. We regret his untimely passing. The authors would like also to thank Giuliana Tromba, Lucia Mancini and Nicola Sodini for their contribution to the experimental work. We are grateful to DISECT Systems Ltd for donating their 3D rendering and telelinking software for this study, and to two anonymous reviewers for their positive feedback on an earlier draft of the manuscript.

\section{References}

Abrami A, Arfelli F, Barroso RC, Bergamaschi A, Billè F, Bregant P, Brizzi F, Casarin K, Castelli E, Chenda V, Dalla Palma L, Dreossi D, Fava C, Longo R, Mancini L, Menk R-, Montanari F, Olivo A, Pani S, Pillon A, Quai E, Kaiser SR, Rigon L, Rokvic T, Tonutti M, Tromba G, Vascotto A, Venanzi C, Zanconati F, Zanetti A, Zanini F (2005) Medical applications of synchrotron radiation at the SYRMEP beamline of ELETTRA. Nuclear Instruments and Methods in Physics Research, Section A: Accelerators, Spectrometers, Detectors and Associated Equipment 548(1-2):221-227

Araujo, V A, Zama U, Dolder H, Lino-Neto J (2005) Morphology and ultrastructure of the spermatozoa of Scaptotrigona xanthotricha Moure (Hymenoptera: Apidae: Meliponini). Brazilian Journal of Morphological Science 22: 137-141 
Bänziger H, Bänziger S (2010) Mammals, birds and reptiles as hosts of Lisotrigona bees, the tear drinkers with the broadest host range (Hymenoptera, Apidae). Mitteilungen der Schweizerischen Entomologischen Gesellschaft 83: 271-282.

Bänziger H, Boongird S, Sukumalanand P, Bänziger S (2009) Bees (Hymenoptera: Apidae) that drink human tears. Journal of the Kansas Entomological Society 82: 135-150

Bettuzzi MS, Casali F, Cornacchia S, Rossi M, Paltrinieri E, Morigi MP, Brancaccio R, Romani D (2004) A new linear array detector for high resolution and low dose digital radiography. Nuclear Instrumentation and Methodology B 213: 227-230

Betz O, Wegst U, Weide D, Heethoff M, Helfen L, Lee W-K \& Cloetens P (2007): Imaging applications of synchrotron X-ray phase-contrast microtomography in biological morphology and biomaterials science.

I. General aspects of the technique and its advantages in the analysis of millimetre-sized arthropod structure. J. Microscopy 227: 51-71

Camargo JMF (2008) Biogeografia histórica dos Meliponini (Hymenoptera, Apidae, Apinae) da região Neotropical, Pp. 13-26. In: P. Vit. (ed.), Abejas sin Aguijón y Valorización Sensorial de su Miel. Mérida, APIBA-DIGECEX, Universidad de Los Andes

Camargo JMF, Roubik DW (1991) Systematics and bionomics of the apoid obligate necrophages: The Trigona hypogea group (Hymenoptera: Apidae; Meliponinae). Biological Journal of the Linnean Society 44: $13-39$

Camargo JMF, Grimaldi DA, Pedro SRM (2000) The extinct fauna of stingless bees (Hymenoptera: Apidae: Meliponini) in Dominican amber: Two new species and redescription of the male of Proplebeia dominicana (Wille and Chandler). American Museum Novitates 3293: 1-24

Cardinal S, Packer L (2007) Phylogenetic analysis of the corbiculate Apinae based on morphology of the sting apparatus (Hymenoptera: Apidae). Cladistics 23: 99-118

Engel MS (1995) Neocorynura electra, a new fossil bee species from Dominican amber (Hymenoptera: Halictidae). Journal of the New York Entomological Society 103(3): 317-323

Engel MS (1996) New augochlorine bees (Hymenoptera: Halictidae) in Dominican amber, with a brief review of fossil Halictidae. Journal of the Kansas Entomological Society, Supplement 69(4): 334-345

Engel MS (1997) A new fossil bee from the Oligo-Miocene Dominican amber (Hymenoptera: Halictidae). Apidologie 28: 97-102

Engel MS (2000) A new interpretation of the oldest fossil bee (Hymenoptera: Apidae). American Museum Novitates 3296: 1-11 
Engel MS (2001a) A monograph of the Baltic amber bees and evolution of the Apoidea (Hymenoptera). Bulletin of the American Museum of Natural History 259: 1-192.

Engel MS (2001b) Monophyly and extensive extinction of advanced eusocial bees: Insights from an unexpected Eocene diversity. Proceedings of the National Academy of Sciences, U.S.A. 98: 1661-1664

Engel MS (2004) Geological history of the bees (Hymenoptera: Apoidea). Revista de Tecnologia e Ambiente 10: 9-33

Engel MS (2005) Family-group names for bees (Hymenoptera: Apoidea). American Museum Novitates 3476: 133

Engel MS (2011) Systematic melittology: Where to from here? Systematic Entomology 36(1): 2-15

Feeney DS, Crawford JW, Daniell T, Hallett PD, Nunan N, Ritz K, Rivers M, Young IM (2006) Threedimensional microorganization of the soil-root-microbe system. Microbiology and Ecology 52: 151158

Fuchs A, Schreyer A, Feuerbach S, Korb J (2004) A new technique for termite monitoring using computer tomography and endoscopy. International Journal of Pest Management 50: 63-66

Gerling D, Hermann HR (1978) Biology and mating behavior of Xylocopa virginica L. (Hymenoptera: Anthophoridae). Behavioral Ecology and Sociobiology 3: 99-111

Gerling D, Hurd PD Jr, Hefetz A (1981) In-nest behavior of the carpenter bee, Xylocopa pubescens Spinola (Hymenoptera: Anthophoridae). Journal of the Kansas Entomological Society 54(2): 209-218

Greco MK, Bell M, Spooner-Hart R, Holford P (2006) X-ray computerized tomography as a new method for monitoring Amegilla holmesi nest structure, nesting behaviour and adult female activity. Entomologia Experimentalis et Applicata 120: 71-76

Greco MK, Hoffmann D, Dollin A, Duncan M, Spooner-Hart R, Neumann P (2009) The alternative Pharaoh approach: Stingless bees encapsulate beetle parasites alive. Naturwissenschaften 97(3): 319-323

Greco MK, Jones A, Spooner-Hart R, Holford P (2008) X-ray computerised microtomography (MicroCT): A new technique for assessing external and internal morphology of bees. Journal of Apicultural Research 47: $286-291$.

Greco MK, Spooner-Hart R, Holford P (2005) A new technique for monitoring Trigona carbonaria nest contents, brood and activity using X-ray computerised tomography. Journal of Apicultural Research 44: $97-100$

Grimaldi D (1995) The age of Dominican amber. In Anderson, K. B.; Crelling, J. C. (eds.), Amber, Resinite, and Fossil Resins. American Chemical Society, Washington, DC: 203-217 
Grimaldi D, Engel MS (2005) Evolution of the Insects. Cambridge University Press; Cambridge, UK

Grimaldi D, Bonwich E, Delannoy M, Doberstein S (1994) Electron microscopic studies of mummified tissues in amber fossils. American Museum Novitates 3097: 1-31

Heethoff M, Helfen L, Norton RA (2009) Description of Neoliodes dominicus n.sp. (Acari, Oribatida) from Dominican amber, aided by synchrotron X-ray microtomography. Journal of Paleontology 83: 153-159

Hinojosa-Díaz, I. A.; Engel, M. S. (2008) Juxtocellar structures in euglossine bees: A new character for corbiculate studies (Hymenoptera: Apidae). Beiträge zur Entomologie 58(1): 97-105

Hörnschemeyer T, Beutel RG, Pasop F (2002) Head structures of Priacma serrata LeConte (Coleoptera, Archostemata) inferred from x-ray tomography. Journal of Morphology 252: 298-314

Iturralde-Vinent ME and MacPhee RDE (1996) Age and paleogeographical origin of Dominican amber. Science 273: $1850-1852$

Johnson SN, Read DB, Gregory PJ (2004) Tracking larval insect movement within soil using high resolution Xray microtomography. Ecological Entomology 29(1): 117-122

Kawakita A, Ascher JS, Sota T, Kato M, Roubik DW (2008) Phylogenetic analysis of the corbiculate bee tribes based on 12 nuclear protein-coding genes (Hymenoptera: Apoidea: Apidae). Apidologie 39: 163-175

Lak M, Néraudeau D, Nel A, Cloetens P, Perrichot V, Tafforeau P (2008) Phase contrast X-ray synchrotron imaging: Opening access to fossil inclusions in opaque amber. Microscopy and Microanalysis 14: 251259

Lak M, Fleck G, Azar D, Engel MS, Kaddumi HF, Neraudeau D, Tafforeau P, Nel A (2009) Phase contrast Xray synchrotron microtomography and the oldest damselflies in amber (Odonata: Zygoptera: Hemiphlebiidae). Zoological Journal of the Linnean Society 156: 913-923

Lambert JB, Frye JS, Poinar GO Jr (1985) Amber from the Dominican Republic: An analysis by nuclear magnetic resonance spectroscopy. Archaeometry 27: 43-51

Mateus S, Noll F (2004) Predatory behavior in a necrophagous bee Trigona hypogea (Hymenoptera; Apidae, Meliponini). Naturwissenschaften 91(2): 94-96.

Michener CD (1974) The Social Behavior of the Bees: A Comparative Study. Belknap Press; Cambridge, MA

Michener CD (1982) A new interpretation of fossil social bees from the Dominican Republic. Sociobiology 7: $37-45$

Michener CD (1990) Classification of the Apidae (Hymenoptera). University of Kansas Science Bulletin, 54 (4): $75-164$

Michener CD (2007) The Bees of the World [ $2^{\text {nd }}$ Edition]. Johns Hopkins University Press; Baltimore, MD 
Noll F (1997) Foraging behavior on carcasses in the necrophagic bee Trigona hypogea (Hymenoptera: Apidae). Journal of Insect Behavior 10(3): 463-467

Noll FB, Zucchi R, Jorge JA, Mateus S (1996) Food collection and maturation in the necrophagous stingless bee, Trigona hypogea (Hymenoptera: Meliponinae). Journal of the Kansas Entomological Society, Supplement 69(4): 287-293

Ohl M, Bleidorn C (2006) The phylogenetic position of the enigmatic wasp family Heterogynaidae based on molecular data, with description of a new, nocturnal species (Hymenoptera: Apoidea). Systematic Entomology 31: 321-337

Ohl M, Engel MS (2007) Die Fossilgeschichte der Bienen und ihrer nächsten Verwandten (Hymenoptera: Apoidea). Denisia 20: 687-700

Oliveira FF (2002) The mesotibial spur in stingless bees: A new character for the systematics of Meliponini (Hymenoptera: Apidae) Journal of the Kansas Entomological Society 75(3): 194-202

Perna A, Jost C, Couturier E, Valverde S, Douady S, Theraulaz G (2008) The structure of gallery networks in nests of termite Cubitermes spp. revealed by x-ray tomography. Naturwissenschaften 95: 877-884

Pohl H, Wipfler B, Grimaldi D, Beckmann F, Beutel RG (2010) Reconstructing the anatomy of the 42-millionyear-old fossil $\uparrow$ Mengea tertiaria (Insecta, Strepsiptera). Naturwissenschaften 97: 855-859

Rasmussen, C. \& S.A. Cameron (2010) Global stingless bee phylogeny supports ancient divergence, vicariance, and long distance dispersal. Biological Journal of the Linnean Society. 99: 206-232

Roubik DW (1982) Obligate necrophagy in a social bee. Science 217: 1059-1060

Roubik DW (1989) Ecology and natural history of tropical bees. Cambridge University Press, New York

Rozen JG Jr (1996) A new species of the bee Heterosarus from Dominican amber (Hymenoptera: Andrenidae; Panurginae). Journal of the Kansas Entomological Society, Supplement 69(4): 346-352

Schlüter T, Stürmer W (1982) X-ray examination of fossil insects in Cretaceous amber of N.W.-France. Annales de la Société de Entomologique de France 18(4): 527-529

Serrão JE (2001) A comparative study of the proventricular structure in corbiculate Apinae (Hymenoptera, Apidae). Micron 32: 379-385

Serrão JE (2005) Proventricular structure in solitary bees (Hymenoptera: Apoidea). Organisms, Diversity \& Evolution 5: 125-133

Soltis DE, Senters AE, Zanis MJ, Kim S, Thompson JD, Soltis PS, Ronse de Craene L, Endress PK, Farris JS (2003) Gunnerales are sister to other core eudicots, and exhibit floral features of early-diverging eudicots. American Journal of Botany 90: 461-470 
Soltis DE, Soltis PS, Endress PK, Chase MW (2005) Phylogeny and Evolution of Angiosperms. Sunderland Sinauer Associates, MA

Tafforeau P, Boistel R, Boller E, Bravin A, Brunet M, Chaimanee Y, Cloetens P, Feist M, Hoszowska J, Jaeger JJ, Kay RF, Lazzari V, Marivaux L, Nel A, Nemoz C, Thibault X, Vignaud P, Zabler S (2006) Applications of X-ray synchrotron microtomography for non destructive 3D studies of paleontological specimens. Applied Physics A 83: 195-202

Thorp RW (1979) Structural, behavioral, and physiological adaptations of bees (Apoidea) for collecting pollen. Annals of the Missouri Botanical Gardens 66: 788-812

Tollner EW (1991) X-ray computerised tomography applications in soil ecology. Agriculture, Ecosystems and Environment 34: 251-260

Velthuis HHW, Gerling D (1983) At the brink of sociality: Interactions between adults of the carpenter bee Xylocopa pubescens Spinola. Behavioral Ecology and Sociobiology, 12(3): 209-214

Wille A, Chandler LC (1964) A new stingless bee from the Tertiary amber of the Dominican Republic (Hymenoptera; Meliponini). Revista de Biología Tropical 12(2): 187-195

Wirkner CS and Richter S (2004) Improvement of microanatomical research by combining corrosion cast with MicroCT and 3D reconstruction, exemplified in the circulatory organs of the woodlouse. Microscopy Research and Technique 64: 250-254.

\section{Figures and Captions}

Fig.1 Amber sample selected for study; a piece of polished, semi-clear, light brown amber from the Dominican Republic (Early Miocene: Burdigalian), with many inclusions. The stingless bee is at the widest end (arrow).

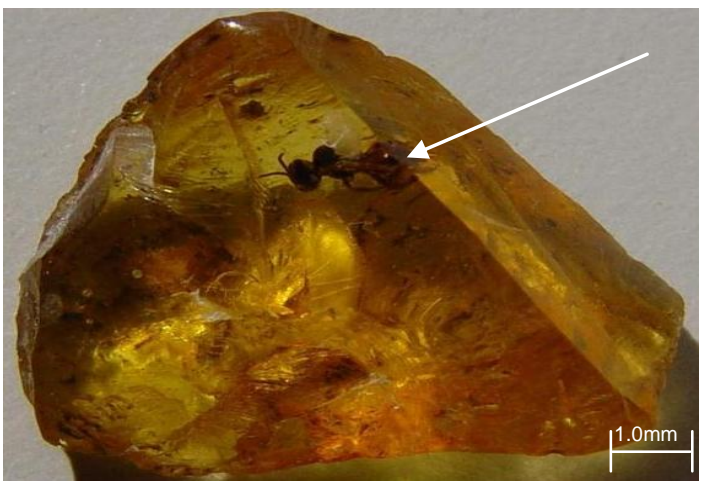


Fig. 2 A schematic diagram of sample positioning for DR. Essentially the only preparation required is that the sample (bee) is positioned securely on the sample stage so that it remains motionless during the scan.

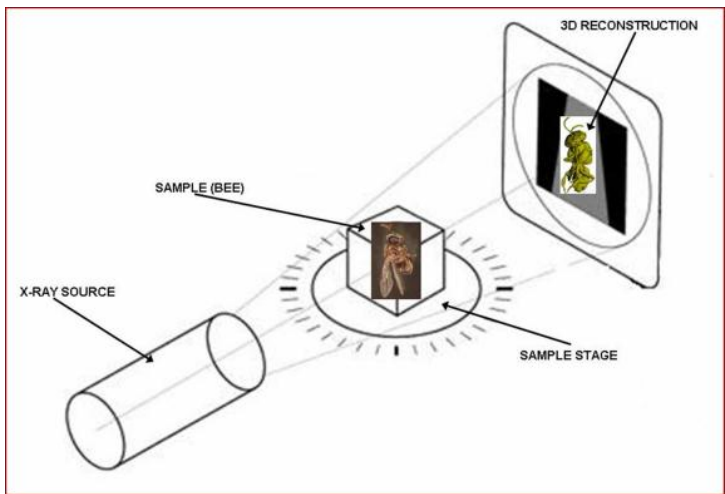

Fig. 3 Air bubbles, fractures, and general thickness of the amber prevent adequate visualisation of the metasoma, posterior mesosoma, and wings. Image taken under optimal optical conditions (increasing or decreasing light intensity further degraded image quality).

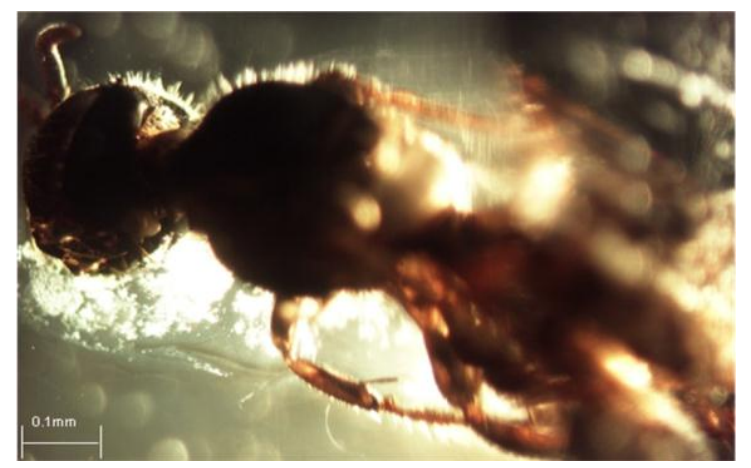

Fig. 4 Volume rendering image of the holotype worker of Proplebeia abdita Greco and Engel n. sp. in Early Miocene (Burdigalian) Dominican amber. Wings (W), flagellomeres (F), base of trochanter (T), tibiae (Tb), tarsi (Ts), the corbicula $(\mathrm{C})$ of the metatibia, and the broadened metabasitarsi $(\mathrm{Bm})$ are all well visualized (TOMOLAB-VGSTUDIO MAX 2.0 rendering). 


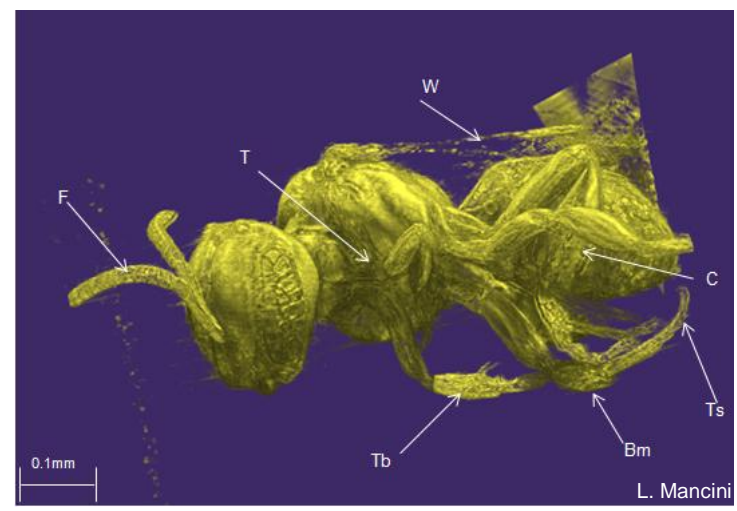

Fig. 5 Sagittal view of Proplebeia abdita Greco and Engel n. sp. holotype. Gross internal structures such as the central body of the brain (CB), retinal zone of the compound eyes (RT), direct (DM) and indirect (IM) flight muscles, and a loaded rectum (RM) were accurately visualised (SYRMEP-BeeView rendering).

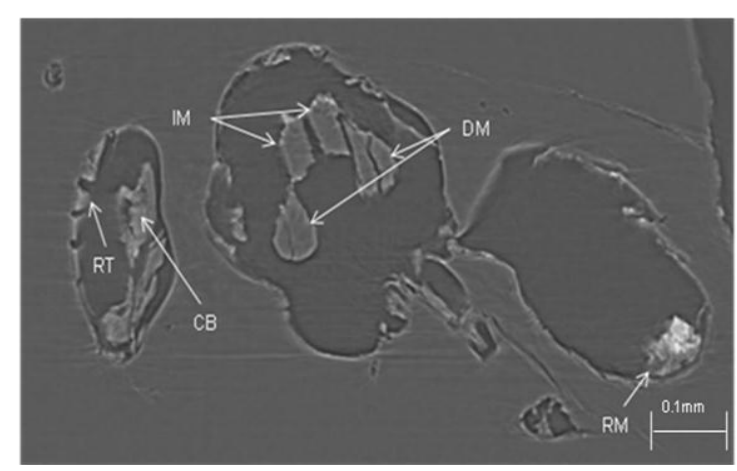

Fig. 6 An axial view of the bee's head capsule. . The brain of this bee was particularly well preserved as evidenced by the optic lobes including the medullae (Me) and lobulae (Lo), antennal lobes (AL), protocerebral lobes $(\mathrm{P})$ and the mushroom bodies (MB). The retinal zone (RT) was also well preserved (Scanco-BeeView rendering). 
Page 18

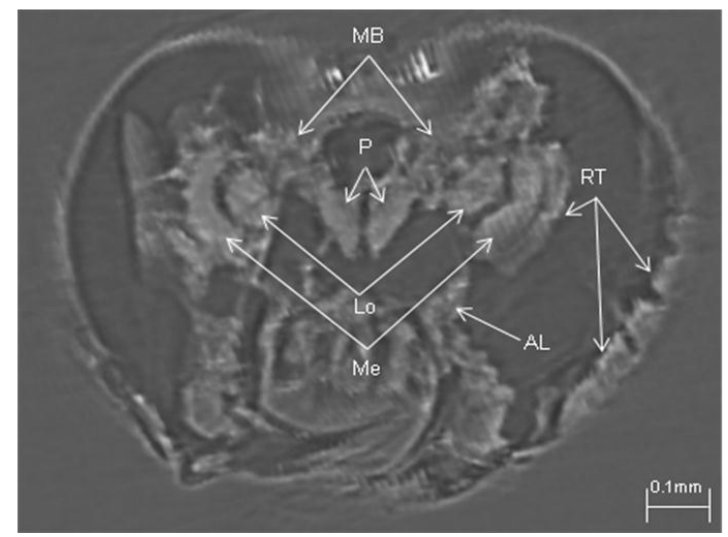

Fig. 7 A 3D reconstruction of the bee showing details of the tridentate mandible (M) with a slight emargination separating the three denticles (D).

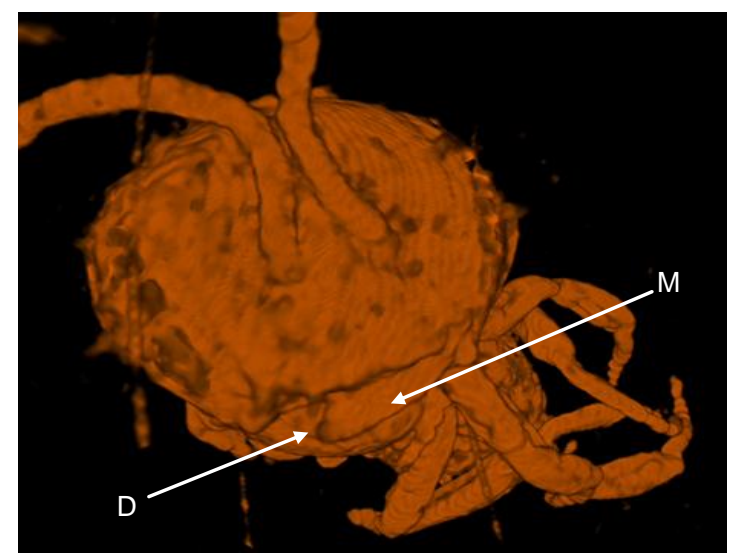

